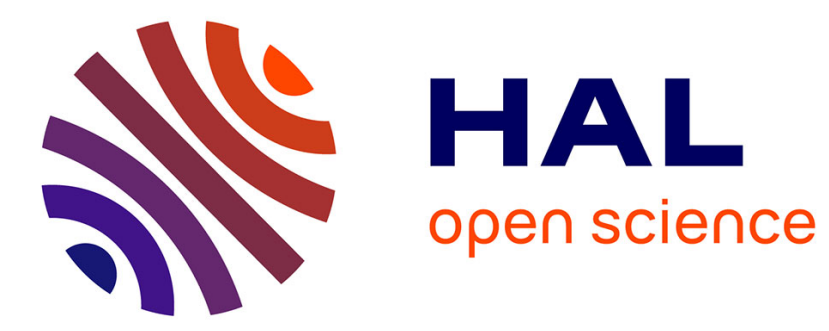

\title{
Paleo-inspired Systems: Durability, Sustainability, and Remarkable Properties
}

Loïc Bertrand, Claire Gervais, Admir Masic, Luc Robbiola

\section{To cite this version:}

Loïc Bertrand, Claire Gervais, Admir Masic, Luc Robbiola. Paleo-inspired Systems: Durability, Sustainability, and Remarkable Properties. Angewandte Chemie International Edition, 2018, 57 (25), pp.7288-7295. 10.1002/anie.201709303 . hal-02128138

\section{HAL Id: hal-02128138 \\ https://hal.science/hal-02128138}

Submitted on 30 May 2019

HAL is a multi-disciplinary open access archive for the deposit and dissemination of scientific research documents, whether they are published or not. The documents may come from teaching and research institutions in France or abroad, or from public or private research centers.
L'archive ouverte pluridisciplinaire HAL, est destinée au dépôt et à la diffusion de documents scientifiques de niveau recherche, publiés ou non, émanant des établissements d'enseignement et de recherche français ou étrangers, des laboratoires publics ou privés. 


\title{
Paleo-inspired systems: Durability, Sustainability and Remarkable Properties
}

\author{
Loïc Bertrand $^{1,2, *}$, Claire Gervais ${ }^{3}$, Admir Masic $^{4}$, Luc Robbiola ${ }^{5}$ \\ 1 IPANEMA, CNRS, ministère de la Culture, UVSQ, Université Paris-Saclay, USR 3461, 91192 Gif-sur-Yvette, France \\ 2 Synchrotron SOLEIL, BP 48 Saint-Aubin, 91192 Gif-sur-Yvette, France \\ ${ }^{3}$ Bern University of Applied Sciences, HKB, Fellerstrasse 11, 3027 Bern, Switzerland \\ ${ }^{4}$ Massachusetts Institute of Technology, Department of Civil and Environmental Engineering, Cambridge, MA, USA \\ 5 TRACES, CNRS, ministère de la Culture, Université Toulouse-Jean Jaurès, UMR 5608, 31100 Toulouse, France \\ * Corresponding author: \\ loic.bertrand@synchrotron-soleil.fr; telephone +33169359780
}

\section{Keywords}

Ancient Materials; Archaeology; Durability; Paleontology; Redox Chemistry

\section{Lead-in}

The process of mimicking properties of specific interest (such as mechanical, optical, and structural) observed in ancient and historical systems is designated here as paleo-inspiration. For instance, recovery in archaeology or paleontology identifies materials that are a posteriori extremely resilient to alteration. All the more encouraging is that many ancient materials were synthesized in soft chemical ways, often using low-energy resources and sometimes rudimentary manufacturing equipment. In this Minireview, ancient systems are presented as a source of inspiration for innovative material design in the Anthropocene.

\section{Short Biographies}

Loïc Bertrand is Director of the IPANEMA European Research platform on Ancient materials. His research interests center on the development of methodologies to study long-term ageing processes and exceptional preservation of biological remnants and materials from archaeological and paleontological sites studied at microscale, manufacturing techniques used in the past, and the provenance of raw materials used to produce archaeological artefacts.

Claire Gervais is Professor in materials chemistry at the Bern University of the Arts and leads a group dedicated to the analysis of ancient materials by synchrotron and simulation techniques. Her research interests focuses on physicochemical processes in natural and cultural materials, with a focus on materials degradation and the development of innovative methods for investigating composite, multiscale materials. 
Admir Masic is Esther and Harold E. Edgerton Career Development Assistant Professor in the Department of Civil and Environmental Engineering at the MIT. His research focuses on the development of high performance in situ and multiscale characterization techniques to investigate complex hierarchically organized materials. His group explores ancient technologies as a source of inspiration for the development of a new generation of durable and sustainable building materials.

Luc Robbiola is CNRS research engineer and expert in Cultural materials science at Toulouse University. $\mathrm{He}$ is a specialist in metallurgy and surface chemistry as well as in conservation-restoration of artworks. His work mostly focuses on the corrosion and protection of copper-based alloys in natural environments, combining investigation on archaeological and historic materials, and on synthetic alloys. His main research applications relate to the diagnosis of alteration and conservation-restoration, and authentication of ancient materials.

\section{Introduction}

From archaeological remains to fossils, historical and ancient materials provide a fundamental window on our past, gathering materiality and function in an integrative manner. ${ }^{[1]}$ These materials are essential to elucidate the origin and evolution of life forms on Earth, ${ }^{[2]}$ are tangible testimonies of past Human activities, ${ }^{[3]}$ and allow assessing anthropic impacts on Earth climate and environment. ${ }^{[4]}$ Less discussed is their potential of inspiration for the design of novel chemical and material systems or devices. Ancient materials have often undergone a high-level of sequential selection and filtering over time, leading to highly-efficient properties, such as in the metallic luster finishes in ancient ceramics. ${ }^{[5]}$ They can be considered as a subcategory of materials produced under extreme conditions, where extreme values are attained in time instead of pressure or temperature. The time component is a fundamental characteristic of their elaboration, evolution and understanding. ${ }^{[6,7]}$ Long-term preservation in natural contexts provides examples of physicochemical resilience - stability over time in a dynamic environment - to environmental conditions up to billions of years. We therefore argue that the added value of their history endow ancient materials with chemical specificities that are of great interest to conceive novel synthetic paleo-inspired systems incorporating functionalities, such as tailored optical response or environmental resilience. In many cases, however, precise knowledge on the raw materials, recipes, and conditions to produce ancient artefacts has been at least partly lost. Some knowledge can be retro-engineered from direct in-depth material studies. The whole process involves the steps of understanding the composition of the collected material with interesting functionalities, designing synthesis routes to reproduce corresponding functionalities, and comparing the properties of the newly produced material to expected performances. This process contributes to a description and fundamental understanding of long-term kinetic and thermodynamic behavior laws of material systems. This review therefore discusses the exceptional potential of identifying properties of interest from direct harvesting in ancient materials. We 
present a selection of examples from the literature and our works that illustrate the diversity of these properties and show how paleo-inspiration could further be developed to design resilient materials, systems with remarkable properties and novel chemical processes with low environmental impact.

\section{Durably Environment-Resilient Materials}

With increasing environmental challenges, durability is a key parameter for the material design. Rising levels of anthropogenic $\mathrm{CO}_{2}$ encourage the development of more sustainable materials. An observation of archaeological and paleontological remains allows identifying a posteriori a range of unexpected preservation cases that have either resisted or been transformed to a new material able to survive the filtering effect produced by changing environmental conditions over a long period of time.

Roman concrete is an exemplary case of long-lasting, resilient and sustainable ancient inorganic material. In the history of concrete material, it represents a technological breakthrough. Ancient Roman structures have withstood millennia of seismic events and environmental pressure, while modern concrete structures constructed with ordinary Portland cement have a predicted lifetime of about 100 years. ${ }^{[8]}$ Addition of 'pozzolana' (volcanic ash) provides binding mortar with 5-8 times greater compressive strength than the pure lime mortar previously used in Ancient Greece. Roman concrete could also set in aqueous environments. Despite advances made on the understanding of their resilience,$^{[9,10]}$ the exact recipe and physicochemical process leading to their environmental stability is still not well defined and represents an active research area in the cement industry (Figure 1A-C). The Iron pillar in New Delhi, about 6 tons and over $7 \mathrm{~m}$ in height, is another remarkable case of century-old durability. ${ }^{[11]}$ Its longevity is attributed to its composition, a phosphorus-rich wrought iron with low carbon content. ${ }^{[2]}$ The passive protective surface remained unaffected by the important material heterogeneity linked to the forging process, including slag inclusions. ${ }^{[13]}$

An archetypal example of paleo-inspiration - from observation to synthesis of novel compounds comes from Maya blue (MB), one of the oldest synthetic pigments. Seen in Central American wall paintings and sculptures from the 8th to the 15th c., MB exhibits remarkable durability and resilience to harsh environments (Figure 1D). MB results from boiling a clay (palygorskite, sepiolite) in the presence of an organic dye (indigo). Its chemical resilience has been attributed to the hydrogen-bonded organic-inorganic complex formed by indigo molecules in the channels of the clay structure. ${ }^{[14]}$ Substitution of the indigo dye led to the design of a range of paleo-inspired hybrid pigments of different hues (Figure 1E-F). ${ }^{[15-17]}$ The clay framework itself could be substituted by zeolites. ${ }^{[18]}$ Multifunctional MB-based materials could be synthesized such as superhydrophobic MB and functionalized "organoclays". ${ }^{[19-21]}$

In the three previous cases, the final goal is to reproduce the ancient materials or at least to transfer their environmental resilience into modern materials. Their study can lead to the design of innovative paleoinspired materials. Ancient artefacts can also be used as "analogues" to assess the long-term evolution of 

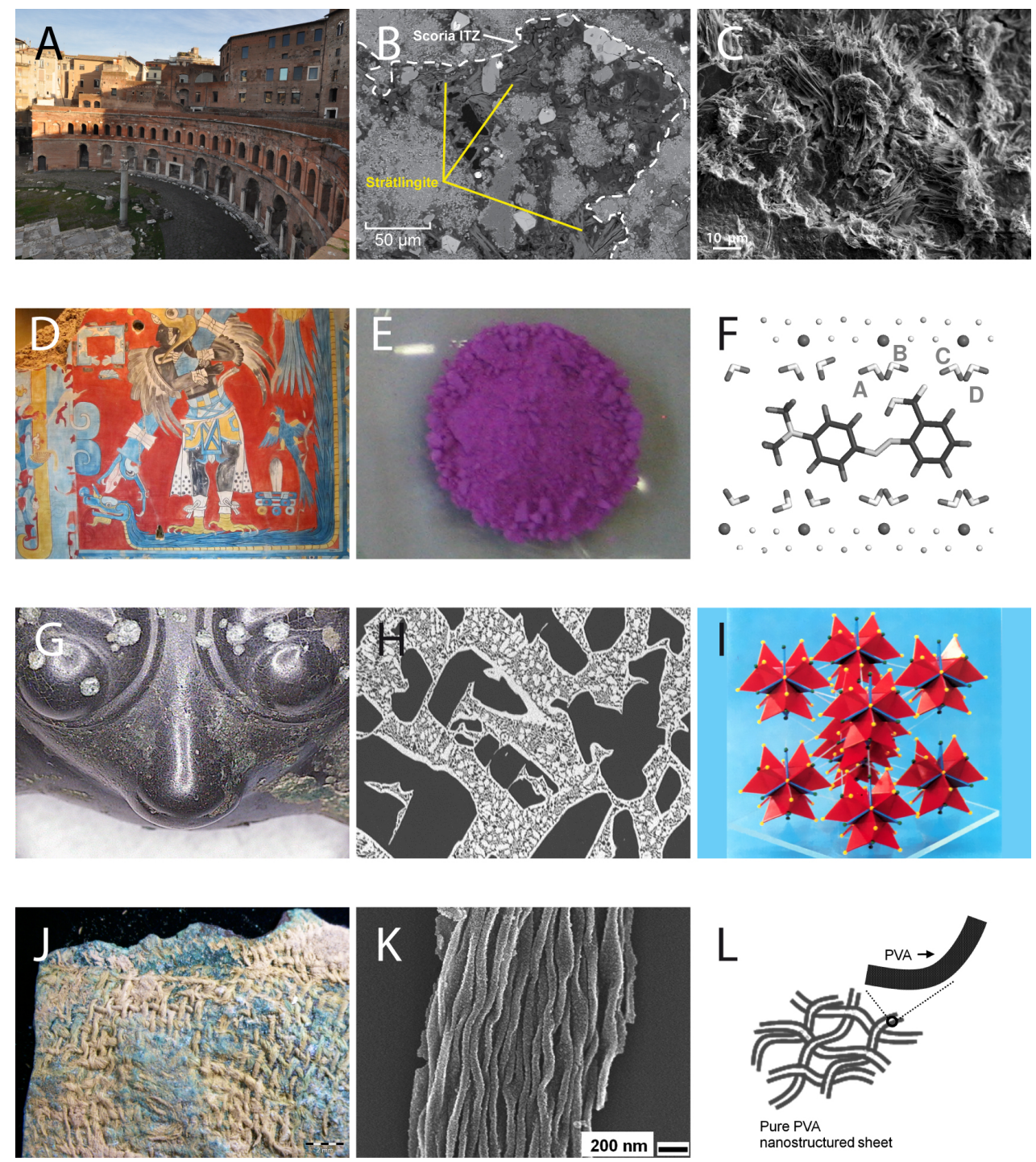

Figure 1: Examples of paleo-inspiration. A-C: the Markets of Trajan constructed in the early 1st C. CE in Rome (credits: M. Vitti; A), mortar of the Great Hall of the Trajan's Markets, interfacial zone along scoria perimeter ${ }^{[10]}(\mathrm{B})$, and authigenic fibrous and platey strätlingite $\mathrm{Ca}_{2} \mathrm{Al}_{2}\left(\mathrm{SiO}_{2}\right)(\mathrm{OH})_{10} \cdot 2.5\left(\mathrm{H}_{2} \mathrm{O}\right)$ crystals, that grow through the relict volcanic scoria and its interfacial zone, forming obstacles to microcrack propagation within the cementitious binding matrix ${ }^{[10]}(\mathrm{C})$. D-F: mural containing Maya Blue paint (D), the methyl red@palygorskite pigment ${ }^{[15]}(E)$, and optimized model structures for methyl red@palygorskite ${ }^{[16]}(F)$. GI: as-cast bronze zoomorphic ornament (Late Iron Age, ca. 300 BCE, La Fosse-Cotheret, France), detail of the central part corresponding to an animal head with a small muzzle and prominent eyes (G), synthetic as-cast $\mathrm{Cu}-\mathrm{Sn}$ bronze (Sn $22.0 \mathrm{wt} \%$ ), SEM-BS image of the $\delta$ phase (in white) within the $(\alpha+\delta)$ eutectoid, surrounding the primary solidified $\alpha$ copper solid solution (in black, full image width: $190 \mu \mathrm{m}$; H), and representation of the octuple unit cell crystal structure of a $\gamma \mathrm{Cu}-\mathrm{Zn}$ brass (416 atoms) on which is based the $\delta$ $\mathrm{Cu}-\mathrm{Sn}$ structure (412 atoms, fcc lattice parameter $a=1.798 \mathrm{~nm}$; I). ${ }^{[99]} \mathrm{J}-\mathrm{L}$ : copper-based slab fragment covered by a mineralized cellulosic textile, Nausharo, Pakistan, IV mill. BCE, musée du Quai Branly (J), FEG-SEM image of "artificially fossilized" zirconia paper ${ }^{[86]}(\mathrm{K})$, and fabrication of hierarchical porous PVA from "artificial fossilization" of cellulose ${ }^{[100]}(\mathrm{L})$. 
modern materials in a range of environments. For example, buried archaeological iron and glass are used to evaluate solutions for the long-term containment of used nuclear fuel. ${ }^{[22,23]}$

Several organic molecules constitutive of plant or animal remains have shown remarkable resilience to long-term chemical degradation. Polymeric materials involved in the exo- and endoskeleton, tegument, appendages of animals and the structural parts of plants (based on chitin, cellulose, keratins, fibroins, collagen, sporopollenin) are particularly prone to exceptional preservation. ${ }^{[24-26]}$ Beyond their intrinsic molecular and folding properties, these molecules are involved in supramolecular architectures that contribute to their longterm resilience. ${ }^{[27]}$ DNA can remain amplifiable, although under a chemically altered form, after millennia, particularly in cold or humid micro-environments, or within specific compact bones. ${ }^{[28-31]} \mathrm{A}$ range of other organic compounds or functional moieties where sufficiently well preserved to be used as markers of past biochemical activities, e.g. heme compounds, ${ }^{[32,33]}$ quinones, ${ }^{[34]}$ and several proteins. ${ }^{[35,36]}$ Weak points in bioorganic molecules such as the amino acid side chains that are prone to long-term racemization or hydrolysis have been identified, ${ }^{[24]}$ an essential milestone in the study of ancient proteomes. ${ }^{[37]}$ Exceptional preservation of supposedly less stable molecules was also reported. Fatty acids, terpenic resins, or carbohydrates were identified in a variety of contexts from food-containing vessels to hydrophobic coatings in archaeological potsherds, adhesives, or ancient art objects. ${ }^{[25,38]}$ Frequent fine-scale association with mineral phases suggests a general mechanism assuring long-term conservation of organic-inorganic complexes. Beside their invaluable help to understand the history of life on Earth and past cultural practices, these examples suggest routes to design organic or organometallic materials with exceptional resilience to the effect of time and to harsh environments. For instance, the protection of nucleic acids within ancient fossils was recently mimicked by encapsulating DNA into amorphous silica spheres, leading to nucleic acids withstanding high temperatures and aggressive oxic environments. ${ }^{[39]}$

\section{Man-made materials with remarkable properties}

Past societies have developed skills and technologies to produce systems that address specific needs, while taking into account available raw materials, local conditions and knowledge. Invention and trial-and-error have led to cultural innovation processes and products optimized towards specific functions, and therefore materials with remarkable properties.

An extreme human chemical creativity has been exerted in producing pigments and dyes for colors where only rare stable compounds exist in nature. The search for alternatives to the expensive blue pigments lapis lazuli, indigo and azurite is particularly illustrative, and led to very early and innovative development of chemical syntheses: Egyptian, ${ }^{[40-43]} \mathrm{Han}^{[44,45]}$ and Maya blues, cobalt minerals and glasses (cobalt and cerulean blue, smalt), turquoise ivory, ${ }^{[46]}$ and more recently the ferrocyanide Prussian Blue, phtalocyanins, up to the contemporary International Klein Blue. A particular level of "perfection" was attained in term of 
optical properties through inspiring early chemical syntheses that are of significant interest for current material chemistry. ${ }^{[11,44,46,47]}$ A similarly appealing example is early Islamic lusters, that are universally renowned for their golden shine obtained from an optimization of surface plasmon resonance effects from copper and silver nanoparticles nucleated at the glaze surface. ${ }^{[48]}$ Verger et al. studied the $\mathrm{ZnAl}_{2-x} \mathrm{Cr}_{x} \mathrm{O}_{4}$ phases employed to color ceramics since the middle of the 19th century by the Sèvres manufacture. These pink to green spinel compounds were optimized for their optical response, as well as for their physicochemical stability during cooling in the melt glaze. ${ }^{[49,50]}$ Improved refractory materials and assessment of the impact of high chromium loading in nuclear glass wastes could benefit from a better understanding of such dissolution / crystallization behavior of these chromium compounds. ${ }^{[50]}$

The chemistry of chromium is indeed not the only case of a potentially highly toxic compounds documented by ancient uses. Archaeology demonstrates advanced chemistry based on heavy elements such as lead over more than four millennia. A range of $\mathrm{Pb}$-based materials were found in ancient Egyptian burials, as paint and cosmetic formulations. In addition to well-known natural minerals such as black lead sulphide (from crushed galena $\mathrm{PbS}$, still used today in traditional make-up), other chemical compounds, e.g. laurionite $\mathrm{PbCl}(\mathrm{OH})$ and phosgenite $\mathrm{Pb}_{2} \mathrm{Cl}_{2} \mathrm{CO}_{3}$, were identified. ${ }^{[51,52]}$ Another typical case is the widespread use of arsenic instead of tin as alloying element in early bronzes (up to $5 \% \mathrm{wt}$ ). Arsenical bronzes have been widely used since the late Chalcolithic in the Middle East ${ }^{[33,54]}$ as well as in ancient Americas. ${ }^{[55]}$ Beyond the undeniable toxicity and health impact of these compounds, this reveals an in-depth knowledge in the specific processing of these toxic materials. Paleo-inspired chemistry could therefore bring innovative concepts towards both a targeted use and processing of toxic substances.

Intriguingly, a range of phases normally identified as thermodynamically metastable or unstable are identified in abundance in ancient systems. A typical example is the $\delta$ phase of tin bronze (Figure 1G-I), one of the earliest alloys produced, widely used over five millennia. According to the $\mathrm{Cu}-\mathrm{Sn}$ equilibrium phase diagram, the temperature existence domain of this phase, hard and brittle, is very limited (621-863 K). ${ }^{[56-59]}$ Although identified as metastable at room temperature in low or high-tin bronzes, as-cast or annealed ancient artefacts prove this intermetallic cubic phase to withstand millennia. ${ }^{[00,61]}$ This discrepancy between full equilibrium and metallurgical steady state still remains to be understood. ${ }^{\left[{ }^{[5,62]}\right.} \mathrm{A}$ number of other metastable inorganic compounds were unexpectedly identified in ancient systems, such as the ferrous hydroxychloride $\beta-\mathrm{Fe}_{2}(\mathrm{OH})_{3} \mathrm{Cl}$ in corroded archaeological iron artefacts, ${ }^{[63]}$ plumbonacrite $\mathrm{Pb}_{10}\left(\mathrm{CO}_{3}\right)_{6} \mathrm{O}(\mathrm{OH})_{6}$ in paints, ${ }^{[64]}$ laurionite $\mathrm{PbCl}(\mathrm{OH})$ in cosmetics from Ancient Egypt, ${ }^{[11]}$ or pseudobrookite $\mathrm{Fe}_{2} \mathrm{TiO}_{5}$ — identified as the main source of the yellow color in Roman marbled sigillata slips. ${ }^{[65]}$ In contrast to synthetized references obtained at a higher temperature, archaeological pseudobrookite is characterized by the presence of magnesium and aluminium atoms within the crystal structure, ${ }^{[5]}$ which could account for their greater chemical stability and high reflective index. This formulation could thus inspire new pigment formulations. The particularly interesting metastable phase $\varepsilon-\mathrm{Fe}_{2} \mathrm{O}_{3}$ was identified in the lustrous black glaze of ancient Jian Chinese potteries from 
the Song dynasty (960-1279 CE). ${ }^{[66]} \varepsilon-\mathrm{Fe}_{2} \mathrm{O}_{3}$ is a rare ferric oxide polymorph, intermediate between hematite $\alpha-\mathrm{Fe}_{2} \mathrm{O}_{3}$ and maghemite $\gamma-\mathrm{Fe}_{2} \mathrm{O}_{3}$, which crystal structure has only been described in the late $90 \mathrm{~s} .{ }^{[67]} \mathrm{At}$ the glaze surface of Jian ceramics, surface crystals of $\varepsilon-\mathrm{Fe}_{2} \mathrm{O}_{3}$ form a 2D dendritic network micrometric in size, ${ }^{[67]}$ which is remarkable as only submicrometric $\varepsilon-\mathrm{Fe}_{2} \mathrm{O}_{3}$ crystals could be synthesized so far in a laboratory environment. ${ }^{[67,68]}$ Large $\varepsilon-\mathrm{Fe}_{2} \mathrm{O}_{3}$ crystals show promise for fundamental solide state physics studies and for applications in new recording media and telecommunication owing to their magnetic properties. ${ }^{[68,69]} \mathrm{A}$ paleoinspired synthesis of $\varepsilon-\mathrm{Fe}_{2} \mathrm{O}_{3}$ could be proposed based on processing a high iron containing glass at elevated temperature in a reducing atmosphere. ${ }^{[66]}$

\section{Materials produced with scarce resources}

Archaeology as ethnology provide numerous examples of ingenious adaptation to specific environments and constraints, including in the context of limited energy resources. In an essay, Molles \& Flonneau described the creativity deployed to circumvent the oil shortage during WWII. ${ }^{[0]}$ Similarly, ancient technologies may inspire sustainable modern practices, as well as system-level solutions locally adapted to problems.

Archaeology reveals reuse and recycling strategies applied to a range of materials: glass, metals, construction materials, etc. ${ }^{[71,72]}$ Past societies developed advanced life cycle management of materials that can be regarded as early "design-for-recycling". Ancient Roman builders used recycled construction materials (e.g. brick or terra cotta fragments) to enhance concrete, opus caementicium (from Latin opus - wall, caementa - aggregate). ${ }^{[73]}$ This was significantly more economical than squared stone and provided opus caementicium with improved static capacity. The embodied energy of ancient Roman cement formula is significantly lower to that of ordinary Portland cement, and could lead to more environmentally-friendly construction materials. ${ }^{[10,74]}$ Steel, aluminum and cement, three major modern construction materials, account for $47 \%$ of industrial $\mathrm{CO}_{2}$ emissions globally. ${ }^{[75]}$ Opportunities across the life cycle of these materials exist to reduce the environmental footprint of buildings and infrastructure. The resulting production of new material and demolition waste can take inspiration from ancient techniques to reduce material impact over the entire product life cycle. Recycling generally reduces the environmental impact of construction materials. However, this process is still being rediscovered. For instance, modern attempts to recycle concrete aggregate led to a decrease in the durability and strength of the new material. ${ }^{[6]}$

Numerous other examples of soft physical and chemical manufacturing processes are provided by archaeological materials. In ancient worlds, many metallic artefacts were produced via a process involving annealing and hammering. This thermo-mechanical process had three functions: shaping, improving mechanical properties, as well as in some cases modifying surface aspects such as in Damascus steel. ${ }^{[7,78]}$ In this way, ancient production techniques may inform new processing methods for modern materials such as regarding the transposition of the damasked approach to copper for providing rich surface patterns. ${ }^{[9]}$ 
An insightful case of soft chemical conversion is the corrosion of copper to cuprite identified in a very early lost-wax cast from the Chalcolithic site of Mehrgarh. ${ }^{[80]}$ Preservation of a submicrometric eutectic structure is observed over centimeters, while about $39 \%$ of initial copper atoms left the original copper metallic structure during oxidation. ${ }^{[80]}$ Long-term pseudomorphic conversion of organic compounds is also often observed. Fossilization is the chemical transformation of an original material in organic imprints or pseudomorph minerals that retains the morphology of the original material. Typical pseudomorph minerals are apatites, pyrite, clay minerals, calcite, and silica (see Briggs ${ }^{[81]}$ and references therein). Exceptional preservation of soft tissues through authigenic mineralization, e.g. preservation of the morphology of muscle fibers, ${ }^{\left[{ }^{[2]}\right.}$ can be observed up to a mineral grain size of a few tens of nanometers. ${ }^{[81]}$ In archaeological sites, organic matter such as textile, leather, or other biological tissues sometimes "mineralize" in contact with iron or copper-based objects while preserving their microstructure at a scale that allows identifying the animal or the plant of origin, yarn manufacturing methods, or weaving techniques. ${ }^{[83]}$ (Figure 1J). Study of ancient cosmetic treatments led to the identification of an interesting reaction product of archaeological wool with keratinous fibers. Nanoparticles of galena $(\mathrm{PbS})$ form from cleavage of disulfide bridges in keratin, with a local ordering controlled by the organic matrix. ${ }^{[84]}$ This offers an elegant synthesis route to the organically-templated nucleation, growth, and

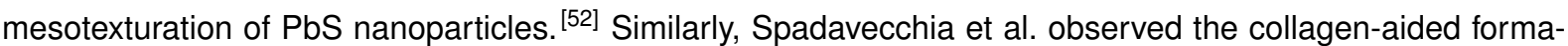
tion of Au nanoparticules in ancient gold-plated ivories. ${ }^{[85]}$

Reproduction of fossilization and mineralization processes at increased speed would allow the templated production of mineral structures complex in shape at potentially nanometric scales, in a sort of "chimie douce" nano-investment casting. Several successful attempts were carried out in this direction. Huang et al. report the nanoreplication of cellulosic fibers in titania $\left(\mathrm{TiO}_{2}\right)$ by mimicking their permineralization after a functionalization of their surface comparable to that possibly involved in fossilization (Figure $1 \mathrm{~K}-\mathrm{L}$ ). ${ }^{[86,87]}$ Mizutani et al. synthesized porous titania, alumina, and zirconia ceramic woods using a similar approach of "artificial" or "synthetic" fossilization. ${ }^{[88]}$

\section{Towards new paleo-inspired material design and processing?}

In addition to the traditional strategy that consists in identifying new physicochemical behavior in pure materials and optimizing their use in new systems, this review suggests that harvesting physicochemical properties from paleontological or archaeological systems can provide remarkable solutions. Several key generic features of ancient materials have been or could be further exploited in modern ones. Many durable ancient materials consist in inorganic matrix incorporating organic molecules, e.g. exceptionally-preserved organics in fossil remains, alumina-supported lake pigments, or mineralized textiles. The chemistry of adjacent inorganic surfaces may play a lead role in stabilizing organic molecules. Even in primarily organic systems, long-term ageing appears to be driven by host-guest interactions. For instance, fading of Prussian Blue (used 
as dye in paintings, watercolors and photography) upon anoxia or intense illumination is significantly modified by the redox interaction with the medium in which it is dispersed. ${ }^{[89]}$ Many ancient materials are impure and built upon a multiscale organization, which may contribute to impeding the emergence of general failure mechanisms thereby further increasing their resilience. Material heterogeneity creates multiple diverse chemical micro-environments (atmosphere, percolating fluids, pressure, temperature) that could allow investigating the link between local microstructure and reactivity. ${ }^{[00]}$ This solid-state combinatorial probing of material properties agrees well with modern developments in high-throughput material sciences. ${ }^{[1,92]}$ Retro-engineering can be considerably facilitated by access to written or oral ethnological evidence. ${ }^{[93]}$ However, in many cases, synthesis has to be reinvented as knowledge has been lost. Lessons can be learned both from the study of aged materials and of ageing processes themselves. Modelling of ancient materials opens a promising way to characterize and predict new structures and properties but is still in its infancy. ${ }^{[94]}$

The fundamental interest of the paleo-inspired approach rests in the "bottom-up" process of selecting systems in the archaeological and paleontological record that already have demonstrated properties of interest (Figure 2). Ancient solutions have often been developed as a whole in integrated multifunctional systems

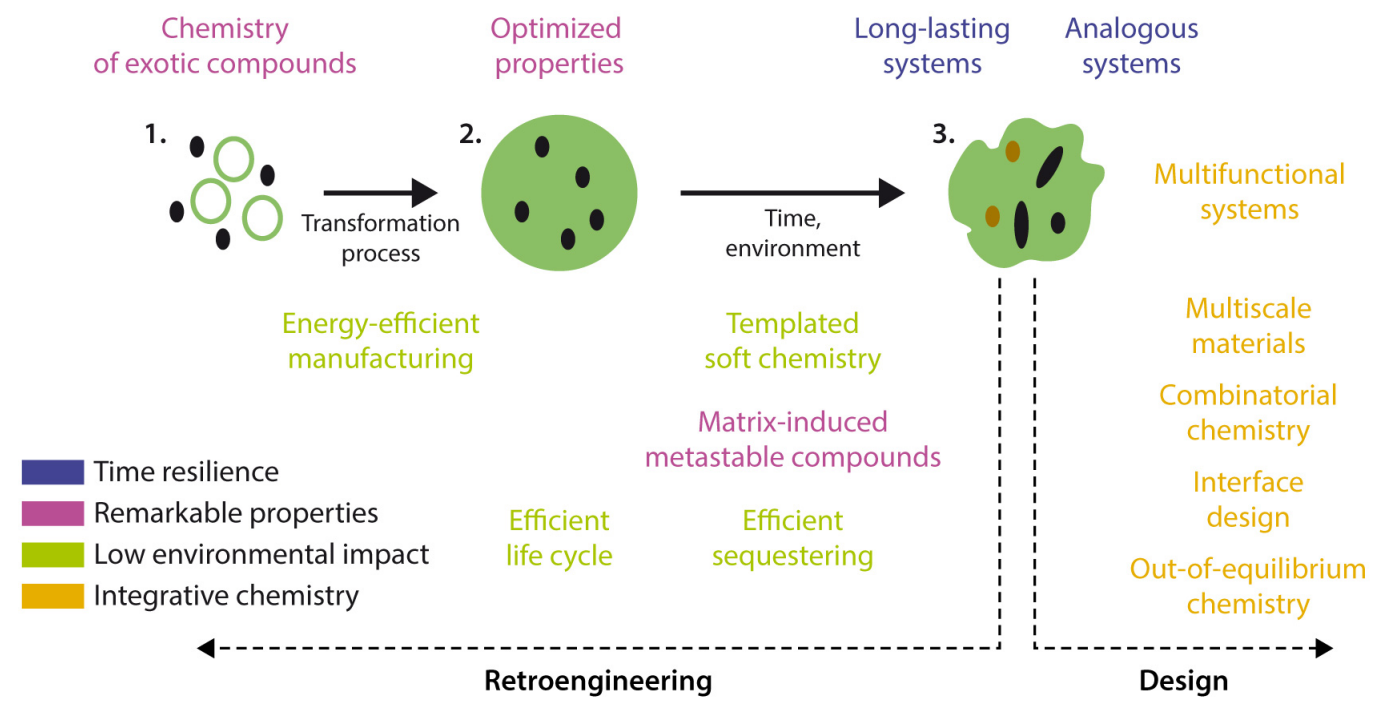

Figure 2: The paleo-inspired chemistry approach. A thorough understanding of ancient systems (material and functional aspects) allows application of their transformation processes or of specific physicochemical properties to new materials and devices. Long-term alteration and ageing conducts from raw materials $\mathbf{1}$, to an elaborated system 2 (for anthropic systems), and to their current transformed state $\mathbf{3}$.

that synergistically connects materials, material interfaces, and functions. For instance, Maya Blue "combines the color of the organic pigment and the resistance of the inorganic host, [and is] a synergic material, with properties and performance well beyond those of a simple mixture of its components". ${ }^{95,96]}$ Art materials may have been optimized jointly for a range of functionalities such as optical reflectance, rheology, chemical compatibility, and durability (see for instance Viguerie et al. ${ }^{[97]}$ ). Historical process optimization and taphonomy 
filtering (literally by the "laws of death", which govern material behavior in archaeological and paleontological burial settings) regard the systems in a holistic manner. This goes along with the vision by P. Yang \& J.-M. Tarascon who emphasize on whole system optimization and interface design in materials science towards functional properties and applications, rather than "revolv[ing] around single material component". ${ }^{[1]}$ As for bio-inspiration, paleo-inspiration provides an additional "point of view" ${ }^{[98]}$ that adds up to the toolbox of the material scientist, built on the considerable body of knowledge that can be extracted from the history and behavior of ancient systems.

\section{Summary and Outlook}

Ancient and historical systems are promising sources of inspiration. Systems studied in archaeology, in paleontology, and in cultural heritage are observed a posteriori, after processes of natural and/or cultural selection. ${ }^{[7]}$ Systems that have resisted this filtering exhibit enhanced resilience capacities. A better understanding of their intrinsic properties may both suggest new materials and new route of synthesis to existing ones. Contrarily to pure synthetic materials, ancient systems are often very heterogeneous in chemical composition and morphology. Even the purest ancient compounds generally contain a range of defects and trace elements that may be unequally distributed in the material and often play a lead role in their physicochemical behavior. There is therefore a great interest to increase our level of knowledge on the detailed multi-scale properties of ancient systems, to develop strategies to model their behavior taking into account their complexity, and to mimic the effects of selection processes towards the generation of novel materials and devices

\section{Acknowledgments}

We are particularly grateful to Jean-Paul Itié (Synchrotron SOLEIL) and Mathieu Thoury (IPANEMA) for discussions regarding this work. LB acknowledges support from Région Île-de-France / DIM Matériaux anciens et patrimoniaux, and the European Commission programs IPERION CH and E-RIHS PP (GA. 654028 and 739503). CG acknowledges the Swiss National Science Foundation for her professorship grant (n. 138986). We thank Christophe Moulherat (musée du quai Branly - Jacques Chirac) for access to the mineralized textile from Nausharo, and Marta Bellato (IPANEMA) for the photograph of the textile. AM thanks Linda M. Seymour, Marc Walton, Heather Lechtman, Marco Nicola, Giacomo Chiari, John Ochsendorf, and Mastro Gilberto Quarneti for fruitful discussions. We are indebted to Jianguo Huang (Zhejiang University, Hangzhou), Roberto Giustetto (Univ. Torino), Marie D. Jackson (Univ. Utah), and Toyoki Kunitake for providing high-resolution images of their work. 


\section{References}

[1] P. Yang, J.-M. Tarascon, Nat. Mater. 2012, 11, 560-563.

[2] M. J. Benton, Vertebrate palaeontology, John Wiley \& Sons, Ltd., 4th ed., 2015.

[3] C. Renfrew, P. Bahn, Archaeology: Theories, Methods, and Practice, Thames and Hudson Ltd, London, UK, 7th ed., 2016.

[4] D. F. Dincauze, Environmental archaeology: principles and practice, Cambridge University Press, Cambridge, UK, 2000.

[5] P. Sciau, P. Goudeau, Eur. Phys. J. B 2015, 88, 132.

[6] M. Aucouturier, E. Darque-Ceretti, Chem. Soc. Rev. 2007, 36, 1605-1621.

[7] L. Bertrand, M. Thoury, E. Anheim, J. Cult. Heritage 2013, 14, 277-289.

[8] K. Cochran, T. Townsend, Waste Manage. 2010, 30, 2247-2254.

[9] a) D. Miriello, A. Bloise, G. Crisci, E. Barrese, C. Apollaro, Archaeometry 2010, 52, 668-679; b) D. Miriello, D. Barca, A. Bloise, A. Ciarallo, G. M. Crisci, T. De Rose, C. Gattuso, F. Gazineo, M. F. La Russa, J. Archaeol. Sci. 2010, 37, 2207-2223.

[10] a) M. D. Jackson, E. N. Landis, P. F. Brune, M. Vitti, H. Chen, Q. Li, M. Kunz, H.-R. Wenk, P. J. Monteiro, A. R. Ingraffea, Proc. Ntl Acad. Sci. 2014, 111, 18484-18489; b) M. D. Jackson, S. R. Mulcahy, H. Chen, Y. Li, Q. Li, P. Cappelletti, H.-R. Wenk, Am. Miner. 2017, 102, 1435-1450.

[15] R. Giustetto, O. Wahyudi, Microporous Mesoporous Mat. 2011, 142, 221-235.

[16] R. Giustetto, J. G. Vitillo, I. Corazzari, F. Turci, J. Phys. Chem. C 2014, 118, 19322-19337.

[99] H. Nyman, S. Andersson, Acta Cryst. A 1979, 35, 580-583.

[86] J. Huang, T. Kunitake, J. Am. Chem. Soc. 2003, 125, 11834-11835.

[100] Y. Gu, J. Huang, J. Mat. Chem. 2009, 19, 3764-3770.

[11] J. C. Hudson, Nature 1953, 172, 499-500.

[12] a) R. Balasubramaniam, Corrosion Sci. 2000, 42, 2103-2129; b) R. Balasubramaniam, A. R. Kumar, P. Dillmann, Curr. Sci. 2003, 85, 1546-1555.

[13] R. Balasubramaniam, Curr. Sci. 2003, 84, 534-541. 
[14] a) G. Chiari, R. Giustetto, G. Ricchiardi, Eur. J. Mineral. 2003, 15, 21-33; b) G. Chiari, R. Giustetto, J. Druzik, E. Doehne, G. Ricchiardi, Appl. Phys. A 2008, 90, 3-7; c) M. Sanchez del Rio, E. Boccaleri, M. Milanesio, G. Croce, W. van Beek, C. Tsiantos, G. D. Chyssikos, V. Gionis, G. H. Kacandes, M. Suarez, E. Garcia-Romero, J. Mater. Sci. 2009, 44, 5524-5536.

[17] a) A. Doménech, M. T. Doménech-Carbó, M. L. Vázquez de Agredos-Pascual, Angew. Chem. Int. Ed. 2011, 50, 5741-5744; b) A. Doménech-Carbó, F. M. Valle-Algarra, M. T. Doménech-Carbó, L. OseteCortina, M. E. Domine, RSC Adv. 2013, 3, 20099-20105.

[18] C. Dejoie, P. Martinetto, E. Dooryhee, E. Van Elslande, S. Blanc, P. Bordat, R. Brown, F. Porcher, M. Anne, Appl. Spectrosc. 2010, 64, 1131-1138.

[19] E. Ruiz-Hitzky, P. Aranda, M. Darder, G. Rytwo, J. Mat. Chem. 2010, 20, 9306-9321.

[20] C. Ouellet-Plamondon, P. Aranda, A. Favier, G. Habert, H. Van Damme, E. Ruiz-Hitzky, RSC Adv. 2015, 5, 98834-98841.

[21] Y. Zhang, J. Zhang, A. Wang, J. Mat. Chem. A 2016, 4, 901-907.

[22] D. Neff, P. Dillmann, L. Bellot-Gurlet, G. Béranger, Corrosion Sci. 2005, 47, 515-535.

[23] G. Libourel, A. Verney-Carron, A. Morlok, S. Gin, J. Sterpenich, A. Michelin, D. Neff, P. Dillmann, C. $R$. Geosci. 2011, 343, 237-245.

[24] M. Hofreiter, M. Collins, J. R. Stewart, Q. Sci. Rev. 2012, 33, 1-13.

[25] P. Van Bergen, M. Collinson, D. Briggs, J. De Leeuw, A. Scott, R. Evershed, P. Finch, Acta Bot. Neerl. 1995, 44, 319-342.

[26] S. Dallongeville, N. Garnier, C. Rolando, C. Tokarski, Chem. Rev. 2015, 116, 2-79.

[27] a) L. Bertrand, J. Doucet, P. Dumas, A. Simionovici, G. Tsoucaris, P. Walter, J. Synchrotron Rad. 2003, 10, 387-392; b) L. Bertrand, A. Vichi, J. Doucet, P. Walter, P. Blanchard, J. Archaeol. Sci. 2014, 42, 487-499; c) G. Tsoucaris, L. Bertrand, P. Walter in Molecular and structural archaeology: cosmetic and therapeutic chemicals, Vol. 117 (Eds.: G. Tsoucaris, J. Lipkowski), Kluwer Academic Publishers, 2003, pp. 135-156.

[28] S. Pääbo, Proc. Ntl Acad. Sci. 1989, 86, 1939-1943.

[29] H. Donoghue, M. Spigelman, J. Zias, A. Gernaey-Child, D. Minnikin, Lett. Appl. Microbio. 1998, 27, 265-269.

[30] M. Hofreiter, D. Serre, H. N. Poinar, M. Kuch, S. Pääbo, Nat. Rev. Genet. 2001, 2, 353.

[31] E. Rizzi, M. Lari, E. Gigli, G. De Bellis, D. Caramelli, Genet. Sel. Evol. 2012, 44, 21. 
[32] D. E. Greenwalt, Y. S. Goreva, S. M. Siljeström, T. Rose, R. E. Harbache, Proc. Ntl Acad. Sci. 2013, 110, 18496-18500.

[33] M. H. Schweitzer, M. Marshall, K. Carron, D. S. Bohle, S. C. Busse, E. V. Arnold, D. Barnard, J. Horner, J. R. Starkey, Proc. Nt/ Acad. Sci. 1997, 94, 6291-6296.

[34] K. Glass, S. Ito, P. R. Wilby, T. Sota, A. Nakamura, C. R. Bowers, J. Vinther, S. Dutta, R. Summons, D. E. Briggs et al., Proc. Ntl Acad. Sci. 2012, 109, 10218-10223.

[35] Y. Kaup, U. Weser, J. Inorg. Biochem. 2000, 79, 3-6.

[36] M. Collins, C. Nielsen-Marsh, J. Hiller, C. Smith, J. Roberts, R. Prigodich, T. Wess, J. Csapo, A. Millard, G. Turner-Walker, Archaeometry 2002, 44, 383-394.

[37] E. Cappellini, L. J. Jensen, D. Szklarczyk, A. Ginolhac, R. A. da Fonseca, T. W. Stafford Jr, S. R. Holen, M. J. Collins, L. Orlando, E. Willerslev, M. T. P. Gilbert, J. V. Olsen, J. Proteome Res. 2012, 11, 917-926.

[38] a) R. P. Evershed, A. W. Stott, A. Raven, S. N. Dudd, S. Charters, A. Leyden, Tetrahedron Lett. 1995, 36, 8875-8878; b) M. Regert, S. Colinart, L. Degrand, O. Decavallas, Archaeometry 2001, 43, 549-569.

[39] D. Paunescu, M. Puddu, J. O. Soellner, P. R. Stoessel, R. N. Grass, Nat. Protoc. 2013, 8, 2440.

[40] T. Pradell, N. Salvado, G. D. Hatton, M. S. Tite, J. Am. Ceram. Soc. 2006, 89, 1426-1431.

[41] C. Grifa, L. Cavassa, A. De Bonis, C. Germinario, V. Guarino, F. Izzo, I. Kakoulli, A. Langella, M. Mercurio, V. Morra, J. Am. Ceram. Soc. 2016, 99, 3467-3475.

[42] G. D. Hatton, A. J. Shortland, M. S. Tite, J. Archaeol. Sci. 2008, 35, 1591-1604.

[43] J. Riederer in Artists' pigments. A handbook of their history and characteristics, vol. 3 (Ed.: E. W. FitzHugh), National Gallery of Art, Washington DC, USA, 1997, pp. 23-45.

[44] H. Berke, H. G. Wiedemann, East Asian Sci. Technol. Med. 2000, 17, 94-120.

[45] E. W. FitzHugh, L. A. Zycherman, Stud. Conserv. 1992, 37, 145-154.

[46] I. Reiche, C. Vignaud, B. Champagnon, G. Panczer, C. Brouder, G. Morin, V. A. Solé, L. Charlet, M. Menu, Am. Miner. 2001, 86, 1519-1524.

[47] A. Doménech, M. T. Doménech-Carbó, M. Sánchez del Río, M. L. V. de Agredos Pascual, E. Lima, New J. Chem. 2009, 33, $2371-2379$.

[48] P. C. Gutierrez, T. Pradell, J. Molera, A. D. Smith, A. Climent-Font, M. S. Tite, J. Am. Ceram. Soc. 2010, 93, 2320-2328.

[49] L. Verger, O. Dargaud, G. Rousse, M. Cotte, L. Cormier, J. Am. Ceram. Soc. 2016, 100, 86-95. 
[50] L. Verger, O. Dargaud, N. Menguy, D. Troadec, L. Cormier, J. Non-Cryst. Solids 2017, 459, 184-191.

[51] a) P. Walter, P. Martinetto, G. Tsoucaris, R. Bréniaux, M. A. Lefebvre, G. Richard, J. Talabot, É. Dooryhée, Nature 1999, 397, 483-484; b) M. Cotte, P. Dumas, G. Richard, R. Bréniaux, P. Walter, Anal. Chim. Acta 2005, 553, 105-110.

[52] P. Walter, E. Welcomme, P. Hallegot, N. J. Zaluzec, C. Deeb, J. Castaing, P. Veyssiere, R. Breniaux, J. L. Leveque, G. Tsoucaris, Nano Lett. 2006, 6, 2215-2219.

[53] H. McKerrell, R. Tylecote, Proc. Prehist. Soc., 1972, pp. 209-218.

[54] I. De Ryck, A. Adriaens, F. Adams, J. Cult. Heritage 2005, 6, 261-268.

[55] a) H. Lechtman, J. Field Archaeol. 1996, 23, 477-514; b) H. Lechtman, S. Klein, J. Archaeol. Sci. 1999, 26, 497-526.

[56] D. Hanson, W. T. Pell-Walpole, Chill-cast tin bronzes, Edward Arnold \& Co, London, U.K., 1951.

[57] N. Saunders, A. P. Miodownik, Bull. Alloy Phase Diagrams 1990, 11, 278-287.

[58] S. Fürtauer, D. Li, D. Cupid, H. Flandorfer, Intermetallics 2013, 34, 142-147.

[59] D. Li, P. Franke, S. Fürtauer, D. Cupid, H. Flandorfer, Intermetallics 2013, 34, 148-158.

[60] W. T. Chase, Ancient and historic metals: conservation and scientific research. Proc. Symp. organized by the J. Paul Getty Museum and the Getty Conservation Institute, Nov. 1991, 1994, pp. 85-118.

[61] S. Srinivasan, I. C. Glover, J. Hist. Metallurgy 1995, 29, 69-88.

[62] J. Miettinen, Comput. Mat. Sci. 2006, 36, 367-380.

[63] a) S. Réguer, P. Dillmann, F. Mirambet, Corrosion Sci. 2007, 49, 2726-2744; b) S. Réguer, F. Mirambet, C. Rémazeilles, D. Vantelon, F. Kergourlay, D. Neff, P. Dillmann, Corrosion Sci. 2015, 100, 589-598.

[64] F. Vanmeert, G. Van der Snickt, K. Janssens, Angew. Chem. Int. Ed. 2015, 54, 3607-3610.

[65] a) Y. Leon, P. Sciau, P. Goudeau, N. Tamura, S. Webb, A. Mehta, Appl. Phys. A 2010, 99, 419-425; b) P. Sciau, Y. Leon, P. Goudeau, S. C. Fakra, S. Webb, A. Mehta, J. Anal. At. Spectrom. 2011, 26, 969-976.

[66] C. Dejoie, P. Sciau, W. Li, L. Noé, A. Mehta, K. Chen, H. Luo, M. Kunz, N. Tamura, Z. Liu, Sci. Rep. 2014, 4, 4941.

[67] E. Tronc, C. Chanéac, J. Jolivet, J. Solid State Chem. 1998, 139, 93-104.

[68] L. Machala, J. Tuček, R. Zboril, Chem. Mat. 2011, 23, 3255-3272. 
[69] K. Kelm, W. Mader, Z. Anorg. Allg. Chem. 2005, 631, 2383-2389.

[70] C. Molles, M. Flonneau, La fin du pétrole: histoire de la pénurie sous l'Occupation [The end of oil: history of the shortage under the Occupation], Descartes \& Cie, Paris, France, 2010.

[71] P. J. Bray, A. M. Pollard, Antiquity 2012, 86, 853-867.

[72] M. B. Schiffer, Formation processes of the archaeological record, University of New Mexico Press, Albuquerque, NM, USA, 1987.

[73] C. G. Malacrino, Constructing the ancient world: Architectural techniques of the Greeks and Romans, Getty Publications, Los Angeles, CA, USA, 2010.

[74] P. Degryse, J. Elsen, M. Waelkens, Cem. Concr. Res. 2002, 32, 1457-1463.

[75] J. Allwood, J. Cullen, Sustainable Materials Without the Hot Air: Making Buildings, Vehicles and Products Efficiently and with Less New Material, UIT Cambridge, 2015.

[76] C. Pellegrino, F. Faleschini, Sustainability Improvements in the Concrete Industry: Use of Recycled Materials for Structural Concrete Production, Springer International Publishing, 2016.

[77] M. Reibold, P. Paufler, A. A. Levin, W. Kochmann, N. Pätzke, D. C. Meyer, Nature 2006, 444, 286.

[78] H. Lechtman, Technol. Cult. 1984, 25, 1-36.

[79] T. Gupta in Copper Interconnect Technology, Springer, New York, NY, 2009, Chapter 6, pp. 267-300.

[80] M. Thoury, B. Mille, T. Séverin-Fabiani, L. Robbiola, M. Réfrégiers, J.-F. Jarrige, L. Bertrand, Nat. Comm. 2016, 7, 13356.

[81] D. E. G. Briggs, Annu. Rev. Earth Planet. Sci. 2003, 31, 275-301.

[82] P. Gueriau, L. Bertrand, Microsc. Today 2015, 23, 2-6.

[83] a) H. L. Chen, K. A. Jakes, D. W. Foreman, J. Archaeol. Sci. 1998, 25, 1015-21; b) K. A. Jakes, L. R. Sibley in Archaeological Chemistry vol. III, Vol. 205 (Ed.: J. B. Lambert), American Chemical Society, Washington, DC, USA, 1984, pp. 403-424; c) C. Moulherat, M. Tengberg, J.-F. Haquet, B. Mille, J. Archaeol. Sci. 2002, 29, $1393-1401$.

[84] L. Bertrand, PhD thesis, Université Pierre et Marie Curie Paris 6, Paris, 2002.

[85] J. Spadavecchia, E. Apchain, M. Albéric, E. Fontan, I. Reiche, Angew. Chem. Int. Ed. 2014, 53, 83638366

[87] S. Li, J. Huang, Adv. Mat. 2016, 28, 1143-1158. 
[88] a) M. Mizutani, H. Takase, N. Adachi, T. Ota, K. Daimon, Y. Hikichi, Sci. Technol. Adv. Mat. 2005, 6, 76-83; b) J. L. Townson, Y.-S. Lin, S. S. Chou, Y. H. Awad, E. N. Coker, C. J. Brinker, B. Kaehr, Nat. Comm. 2014, 5, 5665.

[89] a) C. Gervais, M.-A. Languille, G. Moretti, S. Reguer, Langmuir 2015, 31, 8168-8175; b) C. Gervais, M.-A. Languille, S. Reguer, M. Gillet, S. Pelletier, C. Garnier, E. P. Vicenzi, L. Bertrand, J. Anal. At. Spectrom. 2013, 28, 1600-1609.

[90] L. Bertrand, M. Cotte, M. Stampanoni, M. Thoury, F. Marone, S. Schöder, Phys. Rep. 2012, 519, 51-96.

[91] W. F. Maier, K. Stöwe, S. Sieg, Angew. Chem. Int. Ed. 2007, 46, 6016-6067.

[92] M. Iranmanesh, J. Hulliger, Prog. Solid State Chem. 2016, 44, 123-130.

[93] A. Wisner, B. Pavard, T. H. Benchekroun, P. Geslin, Anthropotechnologie: vers un monde industriel pluricentrique, Octares, 1997.

[94] L. Bellot-Gurlet, P. Dillmann, D. Neff in Nanoscience and Cultural Heritage (Eds.: P. Dillmann, L. BellotGurlet, I. Nenner), Springer, 2016, pp. 205-230.

[95] C. Sanchez, L. Rozes, F. Ribot, C. Laberty-Robert, D. Grosso, C. Sassoye, C. Boissiere, L. Nicole, C. R. Chim. 2010, 13, 3-39.

[96] P. Gómez-Romero, C. Sanchez, New J. Chem. 2005, 29, 57-58.

[97] L. de Viguerie, M. Jaber, H. Pasco, J. Lalevée, F. Morlet-Savary, G. Ducouret, B. Rigaud, T. Pouget, C. Sanchez, P. Walter, Angew. Chem. Int. Ed. 2017, 56, 1619-1623.

[98] a) J. M. Harkness, Phys. Perspect. 2002, 4, 456-490; b) B. Bhushan, Phil. Trans. R. Soc. A 2009, 367, 1445-1486 